EISSN: $2706-7947$ ISSN: 2077- 4613

DOI: $10.36632 /$ mejas/2021.11.4.75

Journal homepage: www.curresweb.com

Pages: 959-974

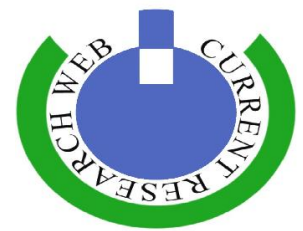

\title{
Comparative study of the physiological performance of two species of Atriplex growing in the same ecological conditions
}

\author{
Taghried M. El-Lamey
}

Ecophysiology Unit, Plant Ecology and Ranges Department, Desert Research Center, Cairo, Egypt

Received: 07 Oct. $2021 \quad$ Accepted: 10 Nov. $2021 \quad$ Published: 25 Nov. 2021

\begin{abstract}
The naturally adapted salt - tolerant plants which are exposed to extreme environmental conditions in the arid and semi-arid regions around the Mediterranean basin possess morphological, anatomical, physiological and biochemical adaptation mechanisms to thrive on salt-affected soils. The aim of this study was to investigate the difference between anatomical structural and physiological adaptation mechanisms of Atriplex nummularia and Atriplex halimus in response to stress conditions. The results revealed that Atriplex halmius performed better under stress conditions than Atriplex nummularia. The important anatomical features of Atriplex nummularia and Atriplex halimus and other Atriplex spp. in relation to environmental stresses are the presence of vesiculated hairs on the leaf surface. Atriplex halmius had specific structural characteristics and different physiological mechanisms for adaption to environmental stresses. It showed a range of morphological and anatomical adaptive traits such as smaller leaf size, more succulent in stem and leaves, more development of vesicular hairs, more development of sclerenchymatic tissues in the hypodermis and in the cortex of the stem as well as in the vascular bundles and in-between the vascular bundles. Also, Atriplex halimus tended to accumulate more minerals $\left(\mathrm{Na}^{+}, \mathrm{Cl}^{-}, \mathrm{P}\right.$ and $\left.\mathrm{Mn}^{2+}\right)$, proline and soluble sugars such as stachyose, mannitol and xylose in high concentration in dry season, which may play role in osmotic adjustment, while Atriplex nummularia accumulated more carbohydrates, glucose, xylose, fructose, mannitol and ribose. This study showed the most important anatomical features and physiological mechanisms of plants that are more tolerant to environmental stresses and subjected to natural selection.
\end{abstract}

Keywords: adaptation, anatomy, Atriplex nummularia, Atriplex halimus, stress.

\section{Introduction}

Under extreme environmental conditions in arid, semi- arid and seasonal coastal areas, a major constraint for plant growth is salinity. The naturally adapted salt - tolerant plants which are exposed to these conditions possess morphological, anatomical, physiological and biochemical adaptation mechanisms to thrive on salt-affected soils. The family of Chenopodiaceae (Amaranthaceous) contains 102 genera and 1400 species: most grow naturally in soils containing much salt (halophytes). Genera include Beta (6 spp.), Chenopodium (100-150 spp.), Salicornia, Anabasis and Atriplex (Evans, 2009). Atriplex is a large genus of the family Amaranthaceae, comprises more than 200 species (Kelley et al., 1982), distributed widely in arid and semi-arid regions around the Mediterranean basin and all over the world (Le Houérou, 1992). Most of them grow in regions with annual rainfall ranging from 200 to 400mm/year (Abu-Zanat et al., 2004). The xero-halophytes saltbushes (Atriplex) are well adapted to harsh environmental conditions and are used widely to provide forage due to their high content of protein (Le Houérou, 1986; Le Houérou, 1991).

The two species of Atriplex; Atriplex nummularia and Atriplex halimus are xero-halophytes perennial $C_{4}$ plants, capable of growing under saline or drought conditions (Le Houèrou, 1986, 1992; Goodin and McKell, 1970; Goodin, 1979; Rogers et al., 2005). They possess the $\mathrm{C}_{4}$ photosynthetic pathway (Zarrinkamar, 2001), in which $\mathrm{CO}_{2}$ is incorporated into the upper and lower epidermis of the leaf surface phosphoenolpyruvate (PEP) to form oxaloacetate through the action of PEP carboxylase.

Corresponding Author: Taghried M. El-Lamey, Ecophysiology Unit, Plant Ecology and Ranges Department, Desert Research Center, Cairo, Egypt. E-mail: lamytaghried_drc@yahoo.com 
The activity of this carboxylating enzyme is increased by $\mathrm{Na}^{+}$, as it is required as an essential micronutrient (Osmond, 1970; Brownell and Crossland, 1972 ) for the translocation of pyruvate cross the chloroplast envelop in a number of $\mathrm{C}_{4}$ species (Maathuis, and Amtmann, 1999).

The small number of $\mathrm{C}_{4}$ plants, represent only about $5 \%$ of the Earth's plant biomass and $3 \%$ of known plant species (Bond et al., 2005), and the agronomic and ecological importance of Atriplex nummularia and Atriplex halimus were among the important factors behind choosing these species as model species, and excellent materials for the investigation of anatomical and physiological mechanisms involved in resistance to abiotic stresses. As the identification of the adaptive mechanism of xero-halophytes species to cope with salt and /or drought is of great interest for scientists to identify the traits of stress tolerance plants. Also, the comparison of these closely related species of Atriplex is expected to give more information about the small differences or factors that contribute to the tolerance of these species to salt or drought stresses.

The aim of this study was to investigate the difference between anatomical structural and physiological adaptation mechanisms of Atriplex nummularia and Atriplex halimus in response to stress conditions.

\section{Materials and Methods}

\subsection{Plant materials}

The aerial parts of Atriplex nummularia and Atriplex halimus were collected from El-Hamam region, Mersa Matruh, Egypt in February and July 2019.The plant were identified and authenticated in the herbarium of Desert Research Center.

\subsection{Ecological Studies:}

\subsubsection{Study area and climatic data}

The study was carried out in El-Hamam region at Mersa Matruh (30 48'54.9"N 29²2'36.3"E). This area is classified as arid with mild winter and warm summer (UNESCO, 1977). The mean annual rainfall was $116.52 \mathrm{~mm}$ (increasing from West to East and from South to North). During the period of study in 2019 , the average annual temperature was $23.3^{\circ} \mathrm{C}$. The average annual maximum and minimum temperatures were 29.1 and $17.8^{\circ} \mathrm{C}$, respectively. While the total annual precipitation was $1.26 \mathrm{~mm}$ and the dry period extended from April to December. The annual average wind speed was $10.1 \mathrm{Km} / \mathrm{h}$. The average annual humidity was $49.9 \%$. These Meteorological data indicated that the studied habitat has an arid type of climate with high temperature especially during the dry period. Osborne et al. (2000) reported that the average annual temperature has increased by $0.75{ }^{\circ} \mathrm{C}$ during the past century and precipitation has shown marked variation throughout the Mediterranean basin.

\subsubsection{Soil Analysis}

Soil samples were collected from the soil supporting the investigated plants at 3 random points at two depths: the first depth from $0-10 \mathrm{~cm}$ and the second depth from 10-30 cm at El Hammam region. Soil texture (granulometric analysis) was determined using the international pipette method according to Gee and Bauder (1986) to determine the percentages of sand, silt and clay. Soil reaction (pH) in soil water suspension (1:2.5) was determined using $\mathrm{pH}$ meter instrument and the EC was measured by electrical conductivity meter. The concentrations of sodium and potassium in the soil solution were determined by using flame photometer (Jenway, PFP-7) and the concentrations of magnesium, calcium, carbonate and bicarbonate ions were determined according to the method of Rowell (1994). The concentration of chloride was determined according to the method of Jackson (1967).

\subsection{Physiological studies}

\subsubsection{Plant water content}

Plant water content, the difference between fresh weight (FW) and dry weight (DW), was calculated on a dry basis using the following formula:

Plant water content $(\mathrm{ml} / 100 \mathrm{gDW})=(\mathrm{FW}-\mathrm{DW}) / \mathrm{DW} \times 100$ 


\subsubsection{Anatomical examination}

Fresh samples of Atriplex nummularia and Atriplex halimus were kept in Ethyl Alcohol solution to fix and prepare them for anatomical studies. Four samples were sectioned by using microtome according to Paraffin Sectioning Method (Bani et al., 2011; Mavi et al., 2011). The staining slices were examined under Leica light microscope model DM-500, the images were obtained by using digital camera Leica ICC 50 HD with LAS E7 software version 2.1.0 2012.

\subsubsection{Determination of photosynthesis pigments}

The contents of photosynthesis pigments, chlorophyll-a (Chl a), chlorophyll-b (Chl b) and carotenoids were determined by the spectrophotometric method (Sumanta et al., 2014). Half gram of fresh leaf was homogenized with $10 \mathrm{ml}$ of $80 \%$ Acetone. The homogenate was centrifuged at 10,000 rpm for $15 \mathrm{~min}$ at $40^{\circ} \mathrm{C}$. then $0.5 \mathrm{ml}$ of supernatant was mixed with $4.5 \mathrm{ml}$ of solvent. The absorbance was read at 663, 644 and $452.5 \mathrm{~nm}$ using Unicam UV300 spectrophotometer. The contents of Chlorophyll-a, Chlorophyll-b and Carotenoids were calculated according to the following equations:

Chl a $=12.25 \mathrm{~A} 663.2-279 \mathrm{~A} 646.8$

$\mathrm{Chl} \mathrm{b}=21.5 \mathrm{~A} 646.8-5.1 \mathrm{~A} 663.2$

$\mathrm{C} \mathrm{x}+\mathrm{c}=(1000 \mathrm{~A} 470-1.82 \mathrm{Ca}-85.02 \mathrm{Cb}) / 198$

Where: $\mathrm{A}=$ Absorbance, $\mathrm{Chl} \mathrm{a}=$ chlorophyll $\mathrm{a}, \mathrm{Chl} \mathrm{b}=$ chlorophyll $\mathrm{b}, \mathrm{C} \mathrm{x}+\mathrm{c}=$ carotenoids and the results were expressed as $(\mathrm{mg} / 100 \mathrm{gFW})$.

\subsection{Plant Chemical Analysis}

2.4.1. Preparation of samples

The aerial parts of Atriplex nummularia and Atriplex halimus were dried in the oven at $60{ }^{\circ} \mathrm{C}$ and ground to fine powder, then subjected to various analyses.

\subsubsection{Mineral Analysis}

Half gm of dried sample was digested with $10 \mathrm{ml}$ concentrated sulphuric acid on a hot plate at approximately $270{ }^{\circ} \mathrm{C},(2-4 \mathrm{ml})$ of perchloric acid was added until the digested solution become clear.

The solution was allowed to cool, then diluted to $100 \mathrm{ml}$ with distilled water and used for mineral analysis (Baker and Smith,1974).The concentrations of calcium, magnesium, potassium and sodium were determined according to the method of Rowell (1994), while the concentrations of manganese ,copper, zinc and iron were determined by using ICP emission spectroscopy (Jones, 1977). Whereas in the determination of the concentrations of phosphorus and chloride in the plant sample, the plant dry matter was ashed in porcelain crucibles in a muffle furnace at $550^{\circ} \mathrm{C}$ for $4-6$ hours, part of ashed powder was dissolved in $\mathrm{HCl}$ to measure phosphorus contents in the plant by using phosphomolybdate methods (Rowell,1994), while the other part was dissolved in dilute nitric acid $(0.01 \mathrm{~N})$ to extract chloride from ashed material, then titrated with standard silver nitrate (Jackson and Thomas, 1960). Nitrogen (N) content of sample was estimated by the method described by Kjeldahl (1983) and crude protein was calculated as $\mathrm{N} \times 6.25$ (James, 1995).

\subsubsection{Determination of total Carbohydrates}

The total carbohydrates were extracted by dissolving $0.3 \mathrm{gm}$ of plant powder in $10 \mathrm{ml}$ of $3 \% \mathrm{HCl}$. The tube was sealed and heated at $100{ }^{\circ} \mathrm{C}$ for a period of $2-5$ hours. The extracted sugars were estimated using the phenol-sulfuric acid assay (Buysse and Merck, 1993).

\subsubsection{Determination of free proline}

Free proline was determined according to Bates et al. (1973). Half gm of frozen plant material was homogenized in $10 \mathrm{ml}$ of $3 \%$ aqueous sulfosalicylic acid. The homogenates were centrifuged at $6000 \mathrm{rpm}$ and filtrated. In a test tube, two $\mathrm{ml}$ of the filtrate was mixed with equal volumes of acetic acid and ninhydrin reagent $(1.25 \mathrm{mg}$ ninhydrin, $30 \mathrm{ml}$ of glacial acetic acid, $20 \mathrm{ml} 6 \mathrm{M}$ phosphoric acid) and incubated for 60 minutes at $100^{\circ} \mathrm{C}$. The reaction was terminated by placing the tube in an ice bath. Four $\mathrm{ml}$ of toluene was added with stirring. The light absorbance of the toluene was measured at $520 \mathrm{~nm}$. Proline concentration was determined using a standard curve of L-proline. 


\subsubsection{Determination of free sugars \\ 2.4.5.1. Sample preparation}

Free sugars in plant samples were determined by HPLC according to the method of (Zielinski et $a l .$, 2014). The free sugars in plant samples were extracted by dissolving $1 \mathrm{gm}$ of plant powder in $10 \mathrm{ml}$ of Milli-Q water (type 1) and then filtered through a $0.22 \mu \mathrm{m}$ filter membrane (Waters, Milford, MA, USA). An aliquot of $1.5 \mathrm{~mL}$ of these solutions was placed in vials for the analysis.

\subsubsection{Equipment and operating conditions}

The chromatographic system Agilent (series 1200) coupled to the refractive index detector was equipped with a quaternary pump, degasser and auto injector. The chromatographic data were acquired using the Agilent software. The samples obtained as described above were analyzed using an Aminexcarbohydrate HPX-87 column under isocratic condition with deionizes water. The flow rate was 0.5 $\mathrm{mL} / \mathrm{min}$. The column temperature was maintained at $85^{\circ} \mathrm{C}$ and the detector at $50^{\circ} \mathrm{C}$. Sample detection was performed by comparing retention time's standards.

\subsubsection{Determination of total phenolic content}

Samples were prepared at a concentration of $20 \mathrm{mg} / \mathrm{mL}$ in EtOH $80 \%$. The content of total phenolics in plant samples was determined using the Folin-Ciocalteu method as described by Attard (2013). Briefly, $10 \mu \mathrm{L}$ of sample/standard was mixed with $100 \mu \mathrm{L}$ of Folin-Ciocalteu reagent (Diluted 1: 10) in a 96-well microplate. Then, $80 \mu \mathrm{L}$ of $4 \mathrm{~N} \mathrm{Na}_{2} \mathrm{CO}_{3}$ was added and kept in dark for 20 minutes. The absorbance of blue colour was read at $630 \mathrm{~nm}$. The obtained results were recorded using a microplate reader FluoStar Omega. Total phenolic content was calculated from the standard curve equation $(\mathrm{y}=$ $\left.4.1282 \mathrm{x}-0.0894\left(\mathrm{R}^{2}=0.9925\right)\right)$, where $\mathrm{y}$ is the absorbance at $630 \mathrm{~nm}$ and $\mathrm{x}$ is the concentration of gallic acid in $\mathrm{mg} / \mathrm{L}$. The results were expressed as milligrams gallic acid equivalent per gram dry weight used in extraction (mg GAE/g DW).

\subsection{Statistical analysis}

The data were subjected to two-way analysis of variance (ANOVA) and Duncan's multiple-range test $(\mathrm{P} \leq 0.05)$ using the statistical program, CoStat Version 6.311(CoHort soft-ware, Berkeley, CA 94701) according to Steel et al. (1980).

\section{Results and Discussion}

\subsection{Plants description}

Atriplex L. species are euhalophytes Herbs or shrubs. Leaves flat, generally alternate and frequently mealy, scaly or closely tomentose. Flowers polygamous, the male ones with 5 -lobed perianth and 5 stamens, the female ones with the ovary included between 2 flat, leaf-like bracts, connate at base and later growing enclosing the fruit.

The morphological feature of two species of Atriplex; giant saltbush Atriplex nummularia and saltbush Atriplex halimus was described by Täckholm (1974) as follow:

Atriplex. nummularia Lindley: robust, mostly dioecious shrub, up to 2-3 $\mathrm{m}$ in height with large thick rounded leaves, up to $5 \mathrm{~cm}$, long and often as board, frequently sharply dentate. Fruit-perianth rounded-cordate, papery, with eroded-dentate margin and a hardened base. Atriplex. nummularia is introduced from Australia as a forage plant and naturalized.

Atriplex halimus L.: A. halimus is an upright perennial shrub, up to $3 \mathrm{~m}$ in height, branched from the base tall shrub, up to $3 \mathrm{~m}$, with whitish-yellow, coriaceous leaves, the bark being grey-white in colour, and has leaves which are 10-30 $\mathrm{mm}$ long and 5-20 $\mathrm{mm}$ wide. The leaves are highly variable in form, ranging between deltoid-orbicular and lanceolate, and are attenuated at the base with a short petiole. Atriplex halimus is autochthonous and grows through the Mediterranean basin (Walker et al., 2014).

\subsection{The physical and chemical properties of the soil}

The results of soil physical analysis revealed that the soil associated with Atriplex species at ElHamam region was alkaline soil in nature. The soil $\mathrm{pH}$ with an alkaline reaction has been reported to cause nutrient deficiencies in some micronutrients such as phosphorous, nitrogen, copper, zinc, 
manganese and iron, which may lead to negative impacts on the plant physiological mechanisms (Moore, 2004). As shown in Table 1, soil texture was sand, as the percentages of sand were $97.85 \%$ and $96.96 \%$ in the first $(0-10 \mathrm{~cm})$ and second depths $(10-30 \mathrm{~cm})$, respectively. Others (Mojiri and Jalalian 2011; Mojiri et al., 2011) reported that soil sand had a positive effect on plant physiological parameters, as it helps in penetration the roots to the deep soil.

The chemical analysis of soil indicated that the soil particles in the first depth contained the highest content of available soil nutrient (EC) mainly, $\mathrm{Ca}^{++}\left(6.25 \mathrm{meql}^{-1}\right), \mathrm{Na}^{+}\left(8.88 \mathrm{meql}^{-1}\right), \mathrm{Cl}\left(4.85 \mathrm{meql}^{-1}\right)$ and $\mathrm{CaCO}_{3}(2.35 \%)$ compared with that in the second depth (Table 2).

Table 1: Soil physical properties

\begin{tabular}{cccccc}
\hline \multirow{2}{*}{ Location } & Soil & \multicolumn{3}{c}{ Soil Particles Distribution } & \multirow{2}{*}{ Soil Texture } \\
\cline { 3 - 5 } & depth & Sand\% & Silt\% & Clay\% & Class \\
\hline \multirow{2}{*}{ El -Hamam } & $0-10$ & 97.85 & 1.68 & 0.47 & Sand \\
& $10-30$ & 96.96 & 2.01 & 1.03 & Sand \\
\hline
\end{tabular}

Table 2: Soil chemical properties

\begin{tabular}{|c|c|c|c|c|c|c|c|c|c|}
\hline \multirow{2}{*}{ Soil depth } & \multirow{2}{*}{$\begin{array}{c}\text { pH } \\
1: 2.5\end{array}$} & \multirow{2}{*}{$\begin{array}{c}\text { EC } \\
\text { dS } / \mathbf{m}\end{array}$} & \multicolumn{4}{|c|}{$\begin{array}{c}\text { Cation } \\
\text { (milliequivalent/Liter) }\end{array}$} & \multicolumn{2}{|c|}{$\begin{array}{c}\text { Anion } \\
\text { (milliequivalent/Liter) }\end{array}$} & \multirow[b]{2}{*}{$\mathrm{CaCO3} \%$} \\
\hline & & & $\mathbf{C a}^{++}$ & $\mathbf{M g}^{++}$ & $\mathbf{N a}^{+}$ & $\mathbf{K}^{+}$ & $\mathrm{Cl}^{-}$ & $\mathrm{HCO}_{3}^{-}$ & \\
\hline $0-10$ & 8.41 & 1.67 & 6.25 & 0.75 & 8.88 & 0.93 & 4.85 & 8.00 & 2.35 \\
\hline $10-30$ & 8.59 & 1.37 & 2.90 & 1.50 & 8.86 & 0.43 & 2.85 & 4.50 & 1.80 \\
\hline
\end{tabular}

\subsection{The effect of Seasonal variation on plant water content}

As shown in Table 3, there was a significant difference in the content of water between seasons or species. The content of water was significantly decreased in dry to $63.0 \pm 3.68(\mathrm{ml} / 100 \mathrm{gDW})$ in Atriplex nummularia and to $71.10 \pm 6.60(\mathrm{ml} / 100 \mathrm{gDW})$ in Atriplex halimus, the decrease in the water content of plants in the dry season may attributed to the lack of rainfall and the plant exposure to prolonged drought periods of up to six months. This indicated that Atriplex halimus had the capacity to store water more than Atriplex nummularia.

Table 3: The effect of Seasonal variation in plant water content

\begin{tabular}{|c|c|c|c|}
\hline \multicolumn{2}{|c|}{ Atriplex nummularia (ml/100gDW) } & \multicolumn{2}{|c|}{ Atriplex halimus (ml/100gDW) } \\
\hline Winter & Summer & Winter & Summer \\
\hline $138.8 \pm 2.17^{\mathrm{a}}$ & $63.0 \pm 3.68^{c}$ & $101.8 \pm 17.13^{b}$ & $71.10 \pm 6.60^{c}$ \\
\hline
\end{tabular}

Values are expressed as mean \pm SD ( $=3$ ), in each row values followed different letters are significantly different at $\mathrm{p}<0.05$

\subsection{Anatomical characteristics}

The transverse sections of the leaves of Atriplex nummularia and Atriplex halimus L. (Figs.1\&2), showed that Atriplex nummularia and Atriplex halimus had the "Kranz" anatomy with a layer of bundle sheath cells surrounding each vascular bundle, which is considered as the main anatomical feature of the leaves of $\mathrm{C}_{4}$ plants (Troughton and Card,1974; Jacobs, 2001). As the $\mathrm{C}_{4}$ photosynthesis is associated with the compartmentation of photosynthesis between mesophyll and bundle sheath.

As shown in Figs. (1) and (2), the upper and lower epidermis of the leaf surface in all the transverse sections of Atriplex specimens lamina were covered with vesiculated trichomes (Smaoui, et al., 2011) or vesiculated hairs (Zarrinkamar,2001). The vesiculated hair consists of one bladder cell and several stalk cells, embedded in an epidermal cell. These salt bladders are considered as important anatomical feature of Atriplex species, which enable them to grow under salinity stress. They act as salt containers, insulators for heat and water storage tissues. More than $50 \%$ of $\mathrm{Na}^{+}$and $\mathrm{Cl}^{-}$are translocated to the hair (Osmond et al., 1980) to protect the photosynthetic tissues and to help in maintaining the concentration of $\mathrm{K}^{+}$.

The average thickness of the leaf midrib, average length and average width of main vascular bundle were significantly different between species or seasons (Table 4). The average thickness of the leaf midrib of Atriplex nummularia was $500.16 \pm 7.90 \mu \mathrm{m}$ in winter and significantly increased to $513.46 \pm 3.44 \mu \mathrm{m}$ in summer, while that of Atriplex halimus was $358.08 \pm 7.35 \mu \mathrm{m}$ in winter and increased to $571.37 \pm 6.76 \mu \mathrm{m}$ in dry season. succulence in the terms of leaf thickness seems to be the most adaptive 
mechanism as reported in salt tolerant grass, Imperata cylindrica according to Hameed et al. (2009). The increased leaf succulence of Atriplex halimus was due to the enlargement of the hypodermis and palisade parenchyma (Fig.2)
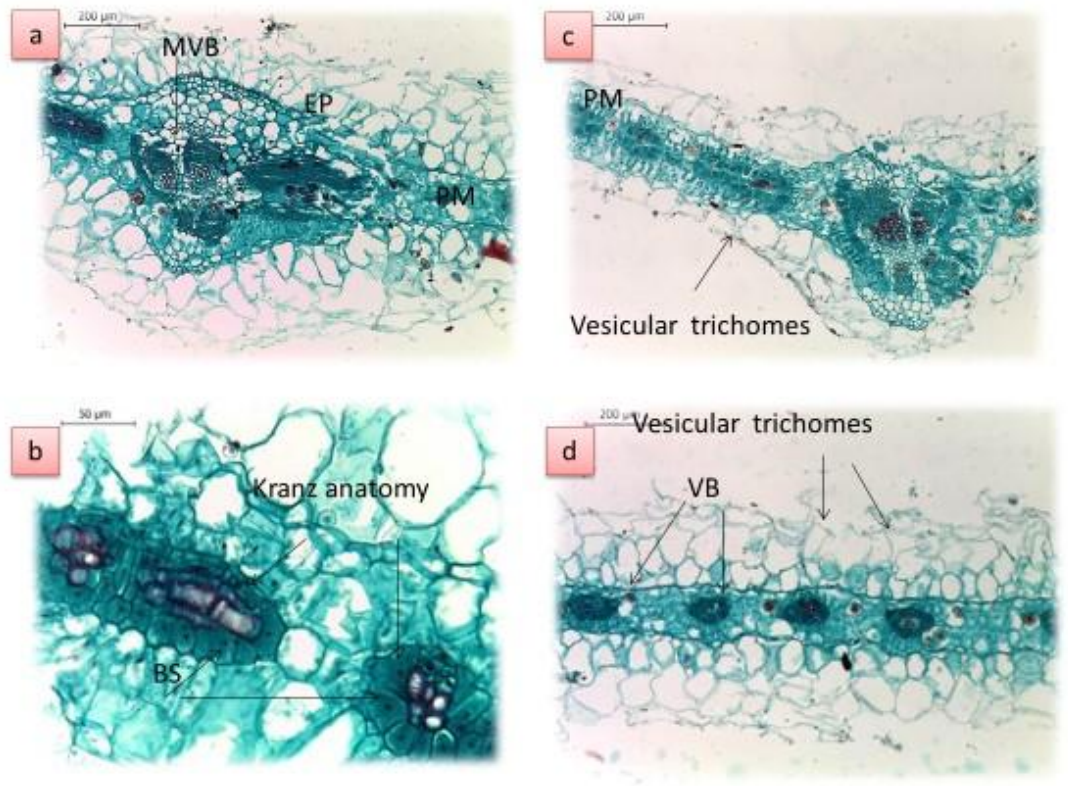

Fig 1: Transverse sections of the lamina of Atriplex nummularia in summer (a-b) and winter (c-d); Ep: epidermis, BS: Bundle sheath, Ca O: Calcium oxalate, PM: Palisade Mesophyll, Ph: Phloem, Scl :

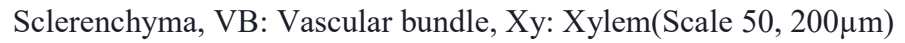
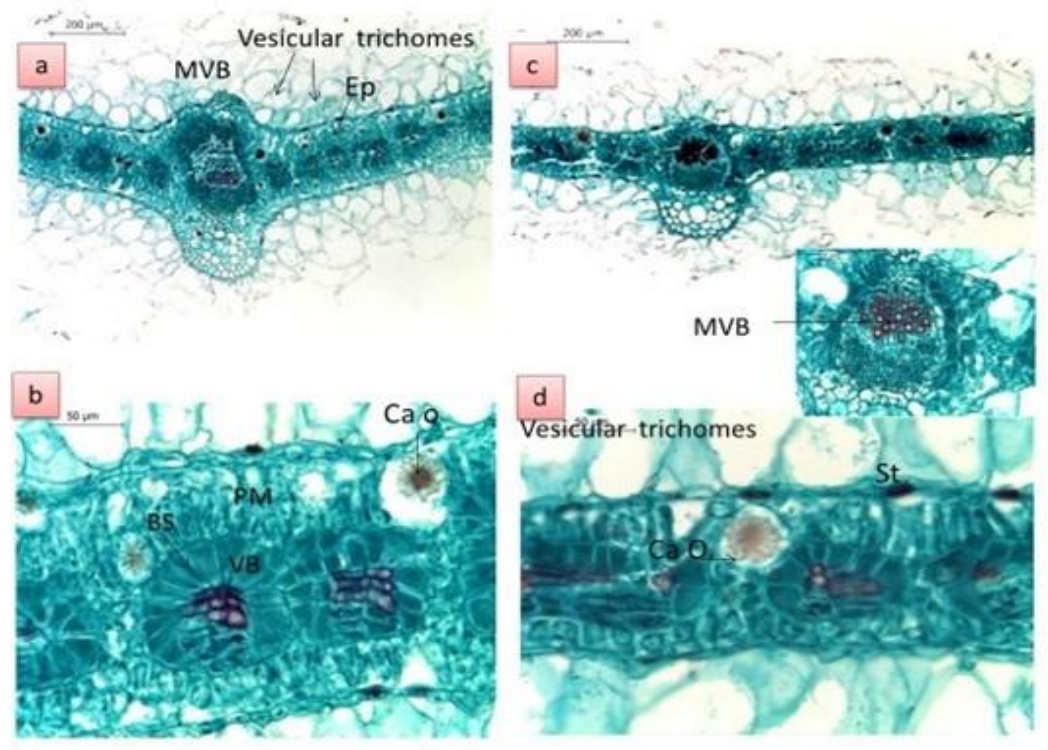

Fig. 2: Transverse sections of the lamina of Atriplex halimus in summer (a-b) and winter (c-d) Ep: epidermis, BS: Bundle sheath Ca O: Calcium oxalate, PM: Palisade Mesophyll, Ph: Phloem, Scl: Sclerenchyma,

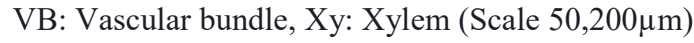


Table 4: The effect of seasonal variations on the anatomical characters of Atriplex nummularia and Atriplex halimus

\begin{tabular}{lllll}
\hline \multirow{2}{*}{ Characters } & \multicolumn{2}{c}{ Atriplex nummularia } & \multicolumn{2}{c}{ Atriplex halimus } \\
\cline { 2 - 5 } & \multicolumn{1}{c}{ Winter } & \multicolumn{1}{c}{ Summer } & \multicolumn{1}{c}{ Winter } & \multicolumn{1}{c}{ Summer } \\
\hline Average Length of leaf vascular bundle $(\mathbf{V B})(\boldsymbol{\mu m})$ & $63.72 \pm 6.29^{\mathrm{d}}$ & $70.25 \pm 0.12^{\mathrm{b}}$ & $68.43 \pm 1.90^{\mathrm{c}}$ & $76.89 \pm 3.18^{\mathrm{a}}$ \\
Average Width of leaf VB $(\boldsymbol{\mu m})$ & $111.7 \pm 5.88^{\mathrm{b}}$ & $118.10 \pm 2.45^{\mathrm{a}}$ & $53.32 \pm 1.69^{\mathrm{d}}$ & $58.03 \pm 3.63^{\mathrm{c}}$ \\
Average thickness of the leaf midrib $(\boldsymbol{\mu m})$ & $500.16 \pm 7.90^{\mathrm{c}}$ & $513.46 \pm 3.44^{\mathrm{b}}$ & $358.08 \pm 7.35^{\mathrm{d}}$ & $571.37 \pm 6.76^{\mathrm{a}}$ \\
Average diameter of stem $(\mathbf{m m})$ & $2.07 \pm 0.08^{\mathrm{a}}$ & $1.42 \pm 0.002^{\mathrm{b}}$ & $1.20 \pm 0.14^{\mathrm{c}}$ & $1.182 \pm 0.03^{\mathrm{c}}$ \\
Average distance between the opposite VB in stem & $521.1 \pm 85.9^{\mathrm{b}}$ & $634.08 \pm 92.3^{\mathrm{a}}$ & $374.57 \pm 18.1^{\mathrm{c}}$ & $511.36 \pm 15.1^{\mathrm{b}}$ \\
Average Length of stem vascular bundle $(\mathbf{V B})(\boldsymbol{\mu m})$ & $256.31 \pm 17.3^{\mathrm{a}}$ & $192.49 \pm 2.79^{\mathrm{c}}$ & $238.03 \pm 8.73^{\mathrm{b}}$ & $199.54 \pm 3.28^{\mathrm{c}}$ \\
\hline Values are expressed as mean $\pm \mathrm{SD}(\mathrm{n}=3)$, in each row values followed different letters are significantly different at $\mathrm{p}<0.05$
\end{tabular}

As shown in Fig. (3), the average area of the leaf surface was significantly different between species. Its values were $1 \pm 0.173 \mathrm{~cm}^{2}$ in Atriplex nummularia and $0.26 \pm 0.057 \mathrm{~cm}^{2}$ in Atriplex halimus. Small leaves are expected to have many advantages in regulating the leaf temperature in hot and dry environments to avoid overheating (Niinemets and Kull, 1994) and have adaptive value for plants evolved for hot environments. Furthermore, the decrease in leaf size with decreasing water availability has been reported by others (Basal et al., 2005; Cramer et al., 2009). Previous studies confirmed that the leaf size variation can significantly modify the integrative photosynthetic activity of the whole leaves, that is, generally higher the mass-based photosynthetic activity of smaller leaves (Poorter and Evans, 1998; Niinemets et al., 2006, 2007). Thus, Leaf size may be a direct product of natural optimum selection (Kleiman and Aarssen, 2007; Tozer et al., 2015).

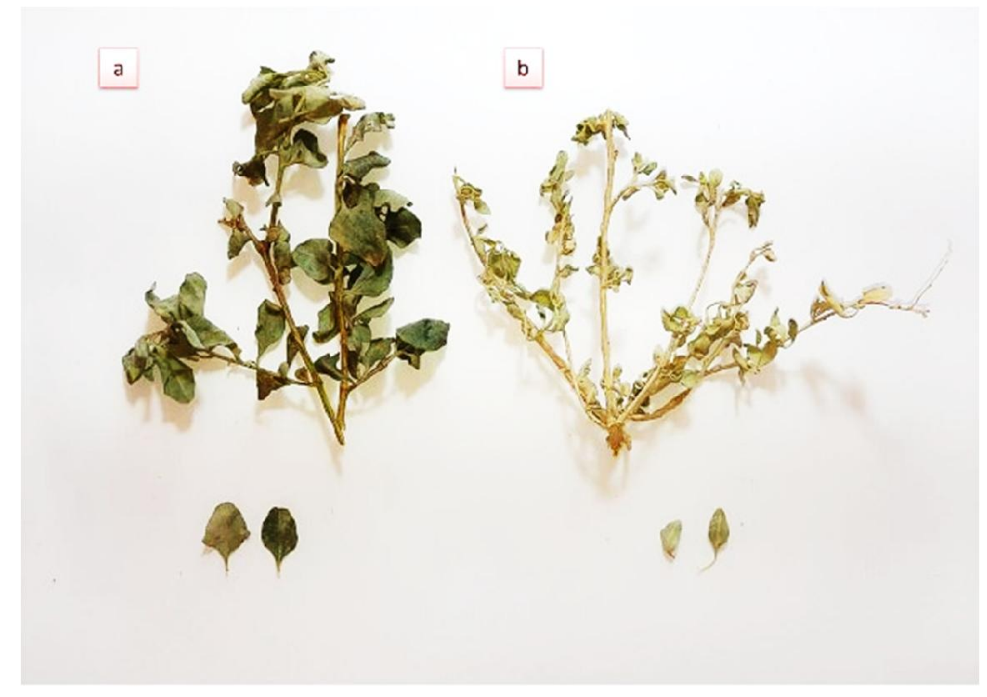

Fig. 3: Morphology of Atriplex nummularia (a) and Atriplex halimus (b)

As Shown in Figs. (4) \& (5), stress conditions in summer season induced significant alternation in stem anatomy of both species of Atriplex. The hypodermal thickness and pith area increased significantly with stress. Whereas the stems of most species of vascular plants form a single cylindrical vascular cambium, the stem of Atriplex nummularia and A. halimus showed an increase in diameter in wet season through the meristematic activity of several successive cambia (Fahn and Zimmermann, 1982).

The transverse sections of the stem of Atriplex nummularia and Atriplex halimus L. showed the presence of vesiculated trichomes connected with the epidermal cell of the stem surface. Average diameter of stem of Atriplex nummularia was $2.07 \pm 0.08 \mathrm{~mm}$ in winter and significantly decreased to $1.42 \pm 0.002 \mathrm{~mm}$ in summer, while in Atriplex halimus L., there was no significant change in stem diameter between seasons.

The vascular bundle is arranged regularly and collaterally forming a circuit around the cell of the pith (parenchymatic cells) and attached with sclerenchymatic cells. In comparing the stem sections of the two species of Atriplex in winter and summer seasons, it was observed that the thickness of the cell 
wall and the number of sclerenchymatic cells, that are in the cortex region and in-between stem vascular bundles were increased significantly in the summer season. Which may protect against water loss (Yentür, 2003; Makbul et al., 2011). The induce of sclerification by salt stress has been reported in other plants such as Spartina alterniflora (Walsh, 1990) and Imperata cylindrica (Hameed et al.,2009).

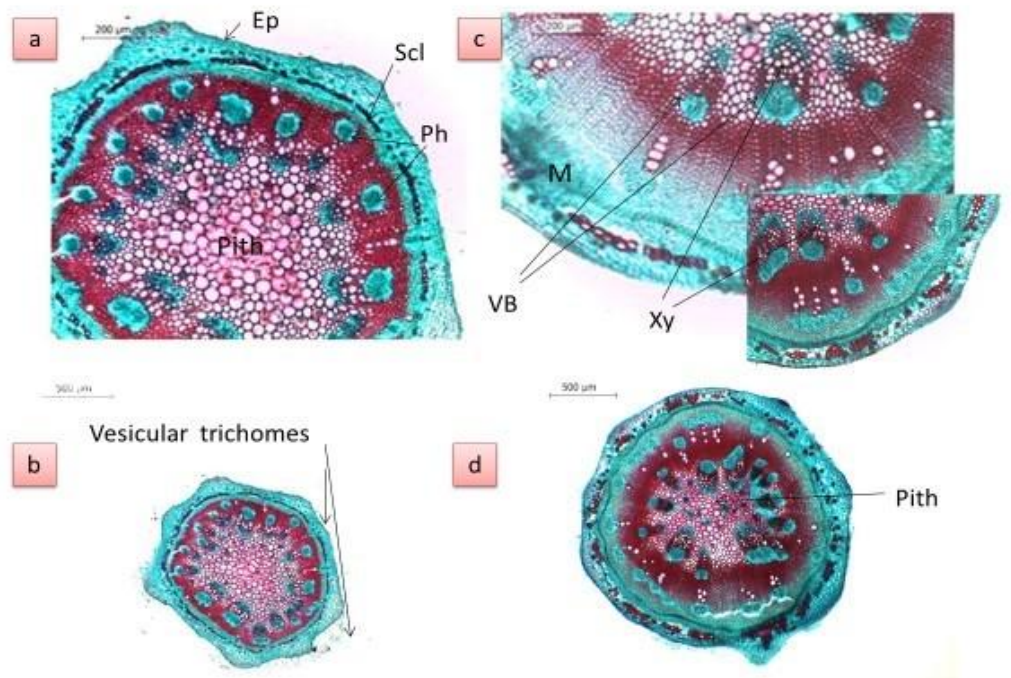

Fig. 4: Transverse sections of the stem of Atriplex nummularia in summer (a-b) and winter (c-d) Ep: epidermis,

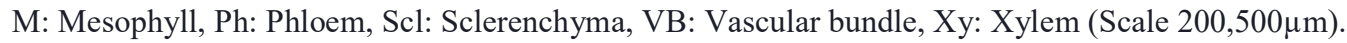
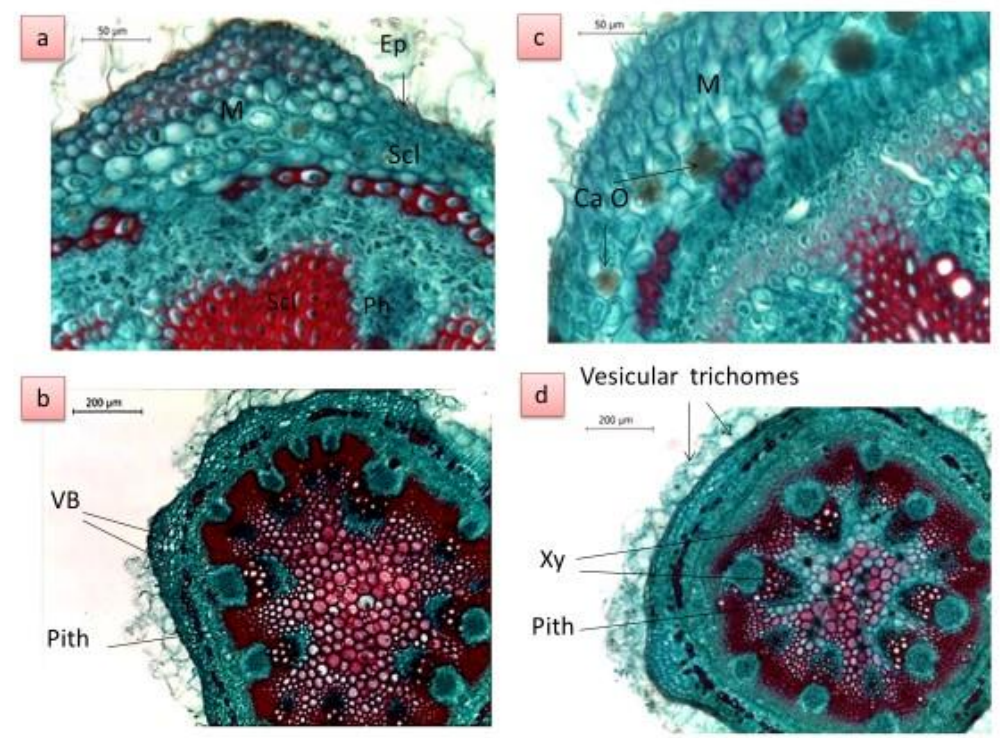

Fig. 5: Transverse sections of the stem of Atriplex halimus in summer (a-b) and winter (c-d); Ep: epidermis, Ca O: Calcium oxalate, M: Mesophyll, Ph: Phloem, Scl : Sclerenchyma, VB: Vascular bundle, Xy: Xylem (Scale50, $200 \mu \mathrm{m}$ ).

The average length of the stem vascular bundle of two species of Atriplex was decreased significantly in response to stress conditions. All the stem and leaf sections were characterized by the presence of crystals of calcium oxalate in the cortex of the stem and in the parenchymatic tissues of the pith as well as in the palisade cells of the leaf. 
3.5. The effect of seasonal variations on the content of photosynthetic pigments in Atriplex species As shown in Table (5), under stress conditions in summer season, the concentration of $\mathrm{Chl}$ a was decreased significantly $(\mathrm{p}<0.05)$ in Atriplex nummularia and Atriplex halimus to $5.53 \pm 0.70$ and $2.53 \pm 0.30 \mathrm{mg} / 100 \mathrm{~g} \mathrm{FW}$, while the concentration of $\mathrm{Chl} \mathrm{b}$ was significantly increased by stress to $9.60 \pm 0.72$ and $3.53 \pm 0.75 \mathrm{mg} / 100 \mathrm{~g} \mathrm{FW}$, respectively.

Measuring the content of essential photosynthetic pigments in plants may help in indicating the efficiency of the photosynthetic process and the rate of energy utilization, it also assists in identifying the physiological performance of the two species of Atriplex under stress conditions. According to Sairam et al., (1997), this reduction in the content of primary photosynthetic pigment (Chl a) under water deficit have been reported for drought-tolerant plants and stress-tolerant genotypes of some crop species. Also, the ratio of $\mathrm{Chl}$ a to $\mathrm{Chl} \mathrm{b}$ in the two species of Atriplex was significantly decreased in the summer season. The same attitude has been recorded in the resistant species of tomato under water stress, which may indicate that photosystem II may have a vital role in protecting the plant against heat and water stress (Ghorbanli et al., 2013).

Regarding the content of carotenoids, the obtained results indicated that there was a significant decrease in the concentration of carotenoids by stress in Atriplex nummularia and a significant increase in Atriplex halimus. The ability of Atriplex halimus to maintain a high content of carotenoid gives the plant a competitive trait that makes it more adaptable to the desert environment than Atriplex nummularia. Due to the antioxidant activity of carotenoid and its capacity to quenching of ${ }^{1} \mathrm{O}_{2}$ and peroxyl radicals (Demmig and Adams ,1996), which may protect cellular components from photooxidative damage during environmental stresses. A previous study performed by Knox and Dodge (1985) proved this important role of carotenoids and revealed that the inhibition of its biosynthesis by norflurazon led to an increase in the production of free radicals and caused oxidative damage to the plant cell.

Table 5: The effect of seasonal variations on the concentration of photosynthetic pigments in Atriplex nummularia and Atriplex halimus

\begin{tabular}{lccccc}
\hline \multirow{2}{*}{ Plant species } & Season & $\begin{array}{c}\text { Chlorophyll a } \\
(\mathbf{m g} / \mathbf{1 0 0 g} \text { FW) }\end{array}$ & $\begin{array}{c}\text { Chlorophyll b } \\
(\mathbf{m g} / \mathbf{1 0 0 g} \text { FW })\end{array}$ & $\begin{array}{c}\text { Carotenoids } \\
(\mathbf{m g} / \mathbf{1 0 0 g} \text { FW })\end{array}$ & Chl a/Chl b \\
\hline \multirow{2}{*}{ Atriplex nummularia } & Winter & $12.5 \pm 0.80^{\mathrm{a}}$ & $1.26 \pm 0.23^{\mathrm{c}}$ & $4.20 \pm 0.34^{\mathrm{b}}$ & $9.98 \pm 2.33^{\mathrm{a}}$ \\
\cline { 2 - 6 } Atriplex halimus & Summer & $5.53 \pm 0.70^{\mathrm{c}}$ & $9.6 \pm 0.72^{\mathrm{a}}$ & $2.26 \pm 0.46^{\mathrm{c}}$ & $0.58 \pm 0.08^{\mathrm{b}}$ \\
\cline { 2 - 6 } & Winter & $7.76 \pm 0.23^{\mathrm{b}}$ & $1.1 \pm 0.34^{\mathrm{c}}$ & $0.86 \pm 0.11^{\mathrm{d}}$ & $7.12 \pm 2.47^{\mathrm{a}}$ \\
\hline
\end{tabular}

Values are expressed as mean $\pm \mathrm{SD}(\mathrm{n}=3)$, in each column values followed different letters are significantly different at $\mathrm{p}<0.05$

\subsection{The effect of seasonal variations on the content of minerals in Atriplex species}

As shown in Table (6), the concentrations of $\mathrm{Na}^{+}$and $\mathrm{Cl}^{-}$were significantly higher in A. halimus than in A. nummularia, under stress conditions in summer season. Their values were $4.34 \pm 0.05$ and $6.17 \pm 0.01 \mathrm{~g} / 100 \mathrm{~g}$ in A. halimus, while in A. nummularia, their values were $2.92 \pm 0.05$ and $4.29 \pm 0.03$ $\mathrm{g} / 100 \mathrm{~g}$, respectively. Like other halophytes, $A$ halimus accumulates the ionic osmolytes, such as $\mathrm{Na}^{+}$, (Nemat Alla et al., 2012) $\mathrm{Cl}^{-}$and other ions (Ben Ahmed et al., 1996; Ben Hassine et al., 2009) in the vacuole in response to salinity. Kader et al. (2011) suggested that the accumulation of $\mathrm{Na}^{+}$in cell vacuole improved the growth by increasing cell volume and enhancement of photosynthesis and sugar synthesis through increasing the photoassimilatory surface area of the leaves (Martinez et al.,2005). Many species of Atriplex have been reported $\mathrm{Na}^{+}$and $\mathrm{Cl}^{-}$accumulation in large amounts, such as A.nummularia (Uchiyama, 1987; Ramo et al., 2004), A. barclayana (Nerd and Pasternak, 1992) and A.hortensis (Wilson et al.,2000). An increase of ion accumulation for osmotic adjustment to decrease the plant osmotic potential is a common trait in many halophytic species such as A. triangularis (Karimi and Ungar, 1984), A. semibacata (Viliers et al., 1996) and A. griffithii (Khan et al., 2000). The accumulation of ions in the vacuole provides cheap solutes for osmotic adjustment, as it is less energy and carbon demanding compared to the adjustment by organic solutes (Flowers et al., 1977; Wyn Jones, 1981; Munns, 2002).

The level of $\mathrm{K}^{+}$of both species of Atriplex was significantly reduced in dry season, its value was decreased significantly from $3.05 \pm 0.04 \mathrm{~g} / 100 \mathrm{~g}$ in winter to $1.85 \pm 0.04 \mathrm{~g} / 100 \mathrm{~g}$ in summer in $A$. 
nummularia, and from $2.04 \pm 0.02$ to $1.82 \pm 0.05 \mathrm{~g} / 100 \mathrm{~g}$ in $A$. halimus. The results indicated that the ratio of $\mathrm{Na}^{+}$to $\mathrm{K}^{+}$in the two species of Atriplex was significantly different between species or seasons, where its value in the summer season in A. halimus $(2.37 \pm 0.08)$ was much higher than that of $A$. nummularia (1.57 \pm 0.05$)$. Due to the similarity of hydrated ionic radii (Tester and Davenport, 2003; Munns, 2005), $\mathrm{Na}^{+}$competes with $\mathrm{K}^{+}$, which cause the uptake of $\mathrm{K}^{+}$to decrease (Nakamura et al., 1990; Marschner,1995). This ratio is mainly influenced by changes in $\mathrm{Na}^{+}$concentration, which are usually relatively much larger than changes in $\mathrm{K}^{+}$, as reported by Negrão et al. (2017). The maintenance of a low ratio of $\mathrm{Na}^{+}$to $\mathrm{K}^{+}$helps plants grow well under saline conditions (Ashraf, 2004).

The increased content of $\mathrm{Na}^{+}$in the aerial parts in most plants is generally associated with relatively low content of $\mathrm{K}^{+}, \mathrm{Ca}^{2+}$ (Munns and Tester ,2008) and /or $\mathrm{Mg}^{2+}$ (Bajji et al.,1998). Thus, the concentrations of $\mathrm{Ca}^{2+}$ and $\mathrm{Mg}^{2+}$ were significantly decreased in the two species of Atriplex in response to stress conditions. This physiological disturbance stimulates the antioxidant system. The ratio of $\mathrm{Na}^{+}$ to $\mathrm{Ca}^{2+}$ was significantly higher in A. halimus $(6.57 \pm 0.35 \mathrm{~g} \%)$ than in A. nummularia $(4.00 \pm 0.25 \mathrm{~g} \%)$, under stress condition in summer season. The concentrations of micronutrient $\mathrm{Fe}^{2+}, \mathrm{Mn}^{2+}$ and $\mathrm{Cu}^{2+}$ were increased significantly in dry season.

Table 6: The effect of seasonal variations on the concentrations of minerals in Atriplex nummularia and Atriplex halimus

\begin{tabular}{lcccc}
\hline \multirow{2}{*}{ Minerals } & \multicolumn{2}{c}{ Atriplex nummularia } & \multicolumn{2}{c}{ Atriplex halimus } \\
\cline { 2 - 5 } & Winter & Summer & Winter & Summer \\
\hline Nitrogen (N) g\% & $1.83 \pm 0.14^{\mathrm{a}}$ & $1.01 \pm 0.04^{\mathrm{b}}$ & $1.30 \pm 0.03^{\mathrm{ab}}$ & $1.54 \pm 0.01^{\mathrm{a}}$ \\
Sodium (Na) g\% & $4.58 \pm 0.05^{\mathrm{a}}$ & $2.92 \pm 0.05^{\mathrm{d}}$ & $3.50 \pm 0.03^{\mathrm{c}}$ & $4.34 \pm 0.05^{\mathrm{b}}$ \\
Potassium(K) g\% & $3.05 \pm 0.04^{\mathrm{a}}$ & $1.85 \pm 0.04^{\mathrm{c}}$ & $2.04 \pm 0.02^{\mathrm{b}}$ & $1.82 \pm 0.05^{\mathrm{c}}$ \\
Na/K & $1.50 \pm 0.02^{\mathrm{d}}$ & $1.57 \pm 0.05^{\mathrm{c}}$ & $1.71 \pm 0.03^{\mathrm{b}}$ & $2.37 \pm 0.08^{\mathrm{a}}$ \\
Calcium (Ca) g\% & $0.92 \pm 0.04^{\mathrm{a}}$ & $0.73 \pm 0.03^{\mathrm{b}}$ & $0.77 \pm 0.02^{\mathrm{c}}$ & $0.66 \pm 0.04^{\mathrm{d}}$ \\
Na/Ca & $4.98 \pm 0.23^{\mathrm{b}}$ & $4.00 \pm 0.25^{\mathrm{d}}$ & $4.41 \pm 0.15^{\mathrm{c}}$ & $6.57 \pm 0.35^{\mathrm{a}}$ \\
Magnesium (Mg) g\% & $1.02 \pm 0.01^{\mathrm{a}}$ & $0.41 \pm 0.03^{\mathrm{d}}$ & $0.90 \pm 0.03^{\mathrm{a}}$ & $0.62 \pm 0.04^{\mathrm{c}}$ \\
Phosphorus (P) g\% & $0.08 \pm 0.01^{\mathrm{b}}$ & $0.06 \pm 0.01^{\mathrm{c}}$ & $0.09 \pm 0.03^{\mathrm{b}}$ & $0.13 \pm 0.02^{\mathrm{a}}$ \\
Chloride (Cl) g\% & $5.53 \pm 0.02^{\mathrm{b}}$ & $4.29 \pm 0.03^{\mathrm{c}}$ & $3.72 \pm 0.05^{\mathrm{d}}$ & $6.17 \pm 0.01^{\mathrm{a}}$ \\
Iron (Fe) g\% & $0.24 \pm 0.004^{\mathrm{c}}$ & $0.42 \pm 0.002^{\mathrm{a}}$ & $0.22 \pm 0.001^{\mathrm{d}}$ & $0.28 \pm 0.001^{\mathrm{b}}$ \\
Manganese (Mn) $\mathbf{~ m g / ~ 1 0 0 g}$ & $16.5 \pm 0.12^{\mathrm{d}}$ & $24.0 \pm 0.59^{\mathrm{b}}$ & $19.6 \pm 0.18^{\mathrm{c}}$ & $47.5 \pm 0.04^{\mathrm{a}}$ \\
Zinc (Zn) $\mathbf{~ m g / 1 0 0 g}$ & $25.70 \pm 0.28^{\mathrm{a}}$ & $18.11 \pm 0.25^{\mathrm{c}}$ & $23.02 \pm 0.08^{\mathrm{b}}$ & $15.73 \pm 0.08^{\mathrm{d}}$ \\
Copper (Cu) $\mathbf{~ m g / 1 0 0 g}$ & $18.6 \pm 0.11^{\mathrm{b}}$ & $23.1 \pm 0.70^{\mathrm{a}}$ & $16.18 \pm 0.02^{\mathrm{c}}$ & $19.2 \pm 0.15^{\mathrm{b}}$ \\
\hline
\end{tabular}

Values are expressed as mean $\pm \mathrm{SD}(\mathrm{n}=3)$, in each row values followed different letters are significantly different at $\mathrm{p}<0.05$

\subsection{The effect of seasonal variations on the concentrations of total carbohydrates and soluble sugars in Atriplex species}

Regarding the concentrations of organic osmolytes (Table7), there was a significant difference between species or seasons in the content of total carbohydrates, its values were increased significantly in A. nummularia from $4.19 \pm 0.10$ in winter to $4.68 \pm 0.06 \mathrm{~g} / 100 \mathrm{~g}$ in summer. Whereas in A. halimus, its values were decreased significantly by stress from $4.98 \pm 0.07$ in winter to $4.86 \pm 0.04 \mathrm{~g} / 100 \mathrm{~g}$ in summer season. Atriplex nummularia respond to stress condition in summer season by accumulation of glucose, xylose, fructose, mannitol and ribose. Whereas in A. halimus, the soluble sugars that increased in concentration in summer season were stachyose, mannitol and xylose. The accumulation of compatible osmolytes assists in maintaining tissue turgor and generates low values of plant water potential (more negative than the external medium) to insure the water uptake (Kan et al., 2000; Kamel, 2007).

\subsection{The effect of seasonal variations on the contents of proline and protein in Atriplex species}

As shown in Table 8, the content of proline was significantly different between species or seasons. Where, the value of proline was significantly reduced in the dry season in A. nummularia, while in $A$. halimus, its value was significantly increased in response to stress conditions. The higher proline accumulation in A. halimus in response to salinity or drought could have been one of the important factors in adaption of $A$. halimus to adverse environmental conditions, this result agrees with Bajji et al., (1998). Various studies have been reported the accumulation of proline as a compatible organic osmotic in the cytoplasm in plants under stress condition to maintain an osmotic equilibrium across the 
tonoplast (Matinez et al., 2003, 2004; Mansou et al.,2005; Desingh and kanagaraj, 2007).In addition to the role of proline as an osmoticum, it acts as an osmo-protectant and involved in stabilizing cellular membranes, protecting proteins and enzymes (Rudolph et al., 1986; Gadallah, 1999; Vinocur and Altman, 2005). It also has the capacity to scavenge free-radical (Lin et al., 2002; Szabados and Savoure, 2010)

Table 7: The effect of seasonal variations on the concentrations of total carbohydrates and soluble sugars in Atriplex nummularia and Atriplex halimus

\begin{tabular}{cccccccccc}
\hline Plant species & Season & $\begin{array}{c}\text { Total } \\
\text { carbohydrates } \\
\mathbf{g} / \mathbf{1 0 0 g}\end{array}$ & $\begin{array}{c}\text { Glucose } \\
\mathbf{g} / \mathbf{1 0 0 g}\end{array}$ & $\begin{array}{c}\text { Xylose } \\
\mathbf{g} / \mathbf{1 0 0 g}\end{array}$ & $\begin{array}{c}\text { Fructose } \\
\mathbf{g} / \mathbf{1 0 0 g}\end{array}$ & $\begin{array}{c}\text { Mannitol } \\
\mathbf{g} / \mathbf{1 0 0 g}\end{array}$ & $\begin{array}{c}\text { Ribose } \\
\mathbf{g} / \mathbf{1 0 0 g}\end{array}$ & $\begin{array}{c}\text { Stachyose } \\
\mathbf{g} / \mathbf{1 0 0 g}\end{array}$ & $\begin{array}{c}\text { Sucrose } \\
\mathbf{g} / \mathbf{1 0 0 g}\end{array}$ \\
\hline $\begin{array}{c}\text { Atriplex } \\
\text { nummularia }\end{array}$ & Winter & $4.19 \pm 0.10^{\mathrm{d}}$ & 0.041 & 0.058 & 0.166 & 0.265 & 0.003 & 6.670 & 0.749 \\
$\begin{array}{c}\text { Atriplex } \\
\text { halimus }\end{array}$ & Winter & $4.68 \pm 0.06^{\mathrm{c}}$ & 0.540 & 0.124 & 0.792 & 3.187 & 0.037 & 5.356 & - \\
\hline
\end{tabular}

Values are expressed as mean $\pm \mathrm{SD}(\mathrm{n}=3)$, in each column values followed different letters are significantly different at $\mathrm{p}<0.05$

Table 8: The effect of seasonal variations on the contents of proline and protein in Atriplex nummularia and Atriplex halimus

\begin{tabular}{cccc}
\hline Species & Season & Proline $\mathbf{~ m} / \mathbf{g}$ & Protein $(\mathbf{m g} / \mathbf{g})$ \\
\hline Atriplex & Winter & $9.03 \pm 0.08^{\mathrm{b}}$ & $114.3 \pm 8.70^{\mathrm{a}}$ \\
\cline { 2 - 4 } nummularia & Summer & $4.18 \pm 0.23^{\mathrm{d}}$ & $62.8 \pm 2.88^{\mathrm{d}}$ \\
\hline $\begin{array}{c}\text { Atriplex } \\
\text { halimus }\end{array}$ & Winter & $7.59 \pm 0.23^{\mathrm{c}}$ & $81.4 \pm 1.94^{\mathrm{c}}$ \\
\cline { 2 - 4 } & Summer & $10.33 \pm 0.26^{\mathrm{a}}$ & $96.6 \pm 0.69^{\mathrm{b}}$
\end{tabular}

Values are expressed as mean \pm SD $(n=3)$, in each column values followed different letters are significantly different at $\mathrm{p}<0.0$

Regarding the concentrations of protein, there was a significant difference between species or seasons. The value of protein was decreased significantly in $A$. nummularia from $114.3 \pm 8.70 \mathrm{mg} / \mathrm{g}$ in winter to $62.8 \pm 2.88 \mathrm{mg} / \mathrm{g}$ in summer. Whereas in A. halimus, its values were increased significantly in response to stress conditions from $81.4 \pm 1.94 \mathrm{mg} / \mathrm{g}$ in winter to $96.6 \pm 0.6 \mathrm{mg} / \mathrm{g}$ in summer season.

\subsection{The effect of seasonal variations on the content of total phenolics in Atriplex species}

As shown in Table (9), the content of total phenolics was significantly different between species or seasons. The highest values of total phenolic content were detected in A. nummularia $\left(4.88 \pm 0.25 \mathrm{mg} \mathrm{g}^{-}\right.$ $\left.{ }^{1}\right)$ and in A. halimus ( $\left.4.19 \pm 0.18 \mathrm{mg} \mathrm{g}^{-1}\right)$ in the dry season. The ability of Atriplex spp. to accumulate a high content of total phenolics under stress conditions gives the plants a competitive trait that makes them more adaptable to the desert environment and oxidative stress. Due to the ability of these compounds to scavenge free radicals and reactive oxygen species and form complexes with the metals that inhibit the activity of oxidizing enzymes and catalyze oxygenation reaction (Sokół1997).

Table 9: The effect of seasonal variations on the concentration of total phenolics in Atriplex nummularia and Atriplex halimus

\begin{tabular}{ccc}
\hline Plant species & Season & Total Phenolics (mg/g) \\
\hline \multirow{2}{*}{ Atriplex nummularia } & Winter & $3.71 \pm 0.11^{\mathrm{c}}$ \\
\cline { 2 - 3 } Atriplex halimus & Summer & $4.88 \pm 0.25^{\mathrm{a}}$ \\
\cline { 2 - 3 } & Winter & $3.21 \pm 0.21^{\mathrm{d}}$ \\
\hline \multirow{2}{*}{ Summer } & $4.19 \pm 0.18^{\mathrm{b}}$
\end{tabular}

Values are expressed as mean $\pm \mathrm{SD}(\mathrm{n}=3)$, in each column values followed different letters are significantly different at $\mathrm{p}<0.05$

\section{General Conclusion}

The two species of Atriplex showed a wide range of anatomical features that aid the plant to be widely distributed in arid and semi-arid regions around the Mediterranean basin, these anatomical 
features included thick epidermis, development of vesiculated trichomes on the leaf and stem surfaces, development of sclerenchymatic tissues in vascular bundles and in-between the vascular bundles, in the hypodermis as well as in the cortex of the stem and the leaf mesophyll tissues. Vesiculated trichomes consists of blabber cells, where the salts are accumulated. When the concentration of salt reached the optimum concentration within these cells, they burst and eliminate the salts.

The anatomical examination of the leaf and stem sections by light microscope indicated the presence of anatomical variations between the two species of Atriplex. These variations were related to the size of leaf, average diameter of stem, average thickness of the leaf midrib, development of sclerenchymatic cells and development of vesiculated trichomes.

The results indicated that each species of Atriplex exhibited a different adaptive mechanism according to genetic structures.

The results showed the anatomical differences between Atriplex spp. that can be associated with their degree of adaptation to external conditions and revealed that Atriplex halmius performed better under stress conditions than Atriplex nummularia. The wide distribution of Atriplex halimus and field observation supported this conclusion. Similarly, Ayyad and El- Ghareeb (1982) demonstrated that Atriplex halmius dominant on elevated, well-drained, saline soils and considered as one of the dominant species in the salt marshes of the western Mediterranean desert of Egypt, in the transitional zones between areas of shallow and deep-water tables. Also, Cañadas et al. (2010) found that A. halimus was the dominant species on the soils of higher salinity. Furthermore, the germination of $A$. halimus seems to be more resistant to salinity than that of $A$. canescens or Atriplex nummularia Lindl as reported by Mâalen and Rahmoune, (2009).

The results revealed that Atriplex halmius has specific structural characteristics and different physiological mechanisms for adaption to environmental stresses. It showed a range of morphological and anatomical adaptive traits such as smaller leaf size, more succulent in stem and leaves, more development of vesicular hairs, more development of sclerenchymatic tissues in vascular bundles and in-between the vascular bundles, in the hypodermis as well as in the cortex of the stem.

The adaptation of Atriplex halimus to the arid environment in term of osmotic adjustment was the most important adaptation mechanism to maintain the water potential more negative than the external medium to ensure the continuous uptake of water. The results revealed that Atriplex halimus tended to accumulate more minerals $\left(\mathrm{Na}^{+}, \mathrm{Cl}^{-}, \mathrm{P}\right.$ and $\left.\mathrm{Mn}^{2+}\right)$, proline and soluble sugars such as stachyose, mannitol and xylose in high concentrations in dry season, which may play role in osmotic adjustment, while Atriplex nummularia accumulated more carbohydrates, glucose, xylose, fructose, mannitol and ribose.

The ability of Atriplex spp. to accumulate a high content of total phenolics under stress conditions gives the plants a competitive trait that makes them more adaptable to the desert environment and oxidative stress.

The study showed the most important anatomical features and physiological mechanisms of plants that are more tolerant to environmental stresses and subjected to natural selection.

\section{References}

Abu-Zanat, M.M., G.B. Ruyle, and N.F. Abdel-Hamid, 2004. Increasing range production from fodder shrubs in low rainfall areas. J. Arid Environ., 59: 205-226.

Ashraf, M., 2004. Some important physiological selection criteria for salt tolerance in plants. Flora, 199: 361-376

Attard, E., 2013. "A rapid microtitre plate Folin-Ciocalteu method for the assessment of polyphenols." Open Life Sciences, 8(1): 48-53.

Ayyad, M.A. and R.E.M. El-Ghareeb, 1982. Salt marsh vegetation of the Eastern Mediterranean desert of Egypt. Vegetatio., 49: 3-19.

Bajji, M., J. Kinet, and S. Lutts, 1998. Salt stress effects on roots and leaves of Atriplex halimus L. and their corresponding callus cultures. Plant Sci., 137: $131-142$.

Baker, A.S. and R.L. Smith, 1974. Preparation of solutions for atomic absorption analysis of Fe, Mn, $\mathrm{Zn}$ and $\mathrm{Cu}$ in plant tissue, J. Agric. Food Chem., 22, 103. 
Bani, B., Ö. Mavi, and N. Adıgüzel, 2011. Morphological and anatomical notes on a local endemic species: Grammosciadium confertum Hub. -Mor. \& Lamond (Umbelliferae). Biological Diversity and Conservation, 4: 1-6.

Basal, H., C.W. Smith, P.S. Thaxton, and J.K. Hemphill, 2005. Seedling drought tolerance in upland cotton. Crop Sci., 45: 766 -771. doi: 10.2135/cropsci2005. 0766

Bates, L.S., R.P. Waldren, and I.D. Teare, 1973. Rapid determination of free proline for water-stress studies. Plant Soil, 39: 205-207.

Ben Ahmed, H., E. Zid, M. El Gazzah, and C. Grignon, 1996. Croissance et accumulation ionique chez Atriplex halimus L. Cah. Agric. 5, 367-372.

Ben Hassine, H., M.E. Ghanem, S. Bouzid, and S. Lutts, 2009. Abscisic acid has contrasting effects on salt excretion and polyamine concentrations of an inland and a coastal population of the Mediterranean xero-halophyte species Atriplex halimus. Ann. Bot. 104, 925e936

Bond, W.J., F.I. Woodward, and G.F. Midgley, 2005. "The global distribution of ecosystems in a world without ire". New Phytologist, 165 (2):525-538. doi:10.1111/j.14698137.2004.01252. x. P MID 15720663.

Brownell, P.F. and C.J. Crossland, 1972. The requirement for sodium as a micronutrient by species having the $\mathrm{C}_{4}$ dicarboxylic photosynthetic pathway. Plant Physiol. 49:794-797

Buysse, J. and X.R. Merck, 1993. An improved colorimetric method to quantify sugar content of plant tissue, Journal of Experimental Botany, 44(267): 1627-1629.

Cañadas, E.M., M.N. Jiménez, F. Valle, E. Fernández-Ondoño, F. Martín-Peinado, and F.B. Navarro, 2010. Soil-vegetation relationships in semi-arid Mediterranean old fields (SE Spain): implications for management. J. Arid. Environ., 74: 1525-1533.

Cramer, M.D., H.J. Hawkins, and G.A. Verboom, 2009. The importance of nutritional regulation of plant water flux. Oecologia, 161: 15-24. doi:10.1007/ s00442-009-1364-3

Demmig-Adams, B. and W.W. Adams, 1996. The role of xanthophylls cycle carotenoids in the protection of photosynthesis. Trends in Plant Science, 1: 21-26. doi.org/10.1016/S1360-1385 (96)80019-7

Desingh, R. and G. Kanagaraj, 2007. Influence of salinity stress on photosynthesis and antioxidative systems in two cotton varieties. Gen. Applied Plant Physiol., 33: 221-234.

Evans, W.C., 2009. Trease and Evans Pharmacognosy $16^{\text {th }}$ edition Edinburgh, London New, York, 26, 604 Elsevier.

Fahn, A. and M.H. Zimmermann, 1982. Development of the successive cambia in Atriplex halimus (Chenopodiaceae). Bot. Gaz. 143, 353-357.

Flowers, T.J., P.F. Troke, and A.R. Yeo, 1977. Mechanism of salt tolerance in halophytes. Ann. Rev. Plant Physiol., 28: 89 - 121.

Gadallah, M.A.A., 1999. Effect of proline and glycinebetaine on Vicia faba responses to salt stress. Biol. Plant. 42: $249-257$.

Gee, G.W. and J.W. Bauder, 1986. Particle-Size Analysis. In: Klute, A., Ed., Methods of Soil Analysis, Part 1. Physical and Mineralogical Methods, Agronomy Monograph No. 9, 2nd Edition, American Society of Agronomy/Soil Science Society of America, Madison, WI, 383-411.

Ghorbanli, M., M. Gafarabad, T. Amirkian, and B.A. Mamaghani, 2013. Investigation of proline, total protein, chlorophyll, ascorbate and dehydroascorbate changes under drought stress in Akria and Mobil tomato cultivars. Iran J. Plant Physiol., 3(2): 651-658.

Goodin, J.R. and C.M. McKell, 1970. Atriplex spp. as a potential forage crop in marginal agricultural areas. In: Proceedings, $11^{\text {th }}$ international grassland conference, Brisbane, Australia. University of Queensland Press, 158-161.

Goodin, J.R., 1979. Atriplex as a forage crop for arid lands. New agricultural crops. In: Ritchie, G.A. (Ed.), AAAS Symposium 38. Westview Press, Boulder, CO, 133-148.

Hameed, M., M. Ashraf, and N. Naz, 2009. Anatomical adaptations to salinity in cogon grass [Imperata cylindrica (L.) Raeuschel] from the Salt Range, Pakistan. Plant Soil 322: 229-238.

Jackson, M.L., 1967. Soil Chemical Analysis. Hall of India Private, New Delhi, India. Printice. Hall Inc., N. J. 248.

Jacobs, S., 2001. Review of leaf anatomy and ultrastructure in the Chenopodiaceae (Caryophyllales). Journal of the Torrey Botanical Society, 236-253 
Jackson, W.A. and G.W. Thomas, 1960. Effect of $\mathrm{KCl}$ and dolometric limestone on growth and ion uptake of sweet potato, Soil Sci., 89: 347-352.

James, C.S., 1995. Analytical chemistry of foods (Blackle Academic and Professional Publisher. An imprint of Champman and Hall) 178.

Jones, J.B., 1977. Elemental analysis of soil extracts and plant tissue ash by plasma emission spectroscopy, Commun. Soil Sci. Plant Analy., 8: 349-365.

Kamel, M., 2007. Osmotic adjustment in three succulent species of Zygophyllaceae, Afric J Ecol. 46: 96-104.

Kan, M.A. I.A. Ungar, and A.H. Showalter, 2000. The effect of salinity on growth, water status and ion content of leaf succulent perennial halophytes, Suaeda fruticosa (L.) Forssk., J Arid Environ., 45: 73-84.

Karimi, S.H. and I.A. Ungar, 1984. The effect of salinity on the ion content and water relations of Atriplex triangularis. In: Tiedemann, A. R., McArthur, E. D., Stutz, H. C., Stevens, R., and Johnson, K. L. (Eds.), Proceeding of the Symposium on the Biology of Atriplex and Related Chenopods, 124 - 130. General Technical Report INT-172, Ogden, Utah: Forest service, U.S. Department of Agriculture. 309.

Kelley, D.B., J.R. Goodin, and D.R. Miller, 1982. Biology of Atriplex. Sen, D. N., and Rajpurohit, K. S. T (Eds.): VS 2 (Tasks for Vegetative Science 2) contribution to the ecology of halophytes. Hague, Netherlands: Dr. W. Junk Publishers, 79 - 107.

Khan, M.A., I.A. Ungar, and A.M. Showalter, 2000. Effects of salinity on growth, water relations and ion accumulation of the subtropical perennial halophytes Atriplex griffithii var. stocksii. Ann Bot., 85: $225-232$.

Kjeldahl, J., 1983. Determination of protein nitrogen in food products, Encyc.Food Agriculture., 28: 757-765.

Kleiman, D. and L.W. Aarssen, 2007. The leaf size/number trade-off in trees. J. Ecol., 95: 376-382. doi: $10.1111 /$ j.1365-2745.2006. 01205.x

Knox, J.P. and A.D. Dodge, 1985. Singlet oxygen and plants. Phytochemistry. 24, 889-896.

Le Houèrou, H.N. (1986). Salt tolerant plants of economic value in the Mediterranean Basin. Reclamation and Revegetation Research, 5: 319-341

Le Houérou, H.N., 1991. Feeding shrubs to sheep in the Mediterranean arid zone: Intake, performance and feed value. IVth International Rangeland Congress Montpelier, France, 2: 639-644.

Le Houérou, H.N., 1992. The role of saltbushes (Atriplex spp.) in arid land rehabilitation in the Mediterranean Basin: a review. Agrofor. Syst., 18 (2): 107-148.

Lin, C.C., Y.T. Hsu, and C.H. Kao, 2002. The effect of $\mathrm{NaCl}$ on proline accumulation in rice leaves. Plant Growth Regul., 36: 275 - 285.

Mâalen, S. and C. Rahmoune, 2009. Toxicity of the salt and pericarp inhibition on the germinationof some Atriplex species. Am. Eurasian J. Toxicol. Sci., 1: 43-49.

Makbul, S., N.S. Güler, N. Durmuş, and S. Güven, 2011. Changes in anatomical and physiological parameters of soybean under drought stress. Turkish Journal of Botany, 35: 369-377.

Marschner, H., 1995. Mineral nutrition of higher plants. Academic Press, London, Orlando, San Diego, New York, Austin, Boston, Sydney, Tokyo, Toronto.

Martìnez, J.P., S. Lutts, A. Schanck, M. Bajji, and J.M. Kinet, 2004. Is osmotic adjustment required for water stress resistance in the Mediterranean shrub Atriplex halimus L? Journal of Plant Physiology, 161(9): 1041-1051. doi:https:// doi.org/10.1016/j.jplph.2003.12.009

Martínez, J.P., J.F. Ledent, M. Bajji, J.M. Kinet and S. Lutts, 2003. Effect of water stress on growth, $\mathrm{Na}^{+}$and $\mathrm{K}^{+}$accumulation and water use efficiency in relation to osmotic adjustment in two populations of Atripex halimus L. Plant Growth Regul., 41: 63-73.

Martínez, J.P., J.M. Kinet, M. Bajji, and S. Lutts, 2005. NaCl alleviates polyethylene glycol-induced water stress in the halophyte species Atriplex halimus L. J. Exp. Bot., 56, 2421e2431.

Maathuis, F.J.M. and A. Amtmann, 1999. $\mathrm{K}^{+}$Nutrition and $\mathrm{Na}^{+}$Toxicity: The Basis of Cellular $\mathrm{K}^{+} / \mathrm{Na}^{+}$ Ratios. Annals of Botany, 84, 123-133. http://dx.doi.org/10.1006/anbo.1999.0912

Mavi, D.Ö., M. Doğan, and E. Cabi, 2011. Comparative leaf anatomy of the genus Hordeum L. (Poaceae). Turkish Journal of Botany, 35: 357-368. doi:10.3906/bot-1003-14

Mojiri, A. and A. Jalalian, 2011. Relationship between Growth of Nitrarial schoberi and Some Soil Properties. Journal of Animal and Plant Sciences, 21(2): 246-250. 
Mojiri, A.J. and N. Honarjoo, 2011. Effects of selected soil properties on growth of Haloxylon SP. in Segzi plain (Iran). J. Anim. Plant Sci., 21(4): 686-691.

Moore, G., 2004. Chemical factors affecting plant growth. Soil Guide - A Handbook for Understanding and Managing Agricultural soils, Chapter 5(Department of Agriculture, Western Australia) 158.

Mozafar, A. and J.R. Goodin, 1970. Vesiculated hairs: a mechanism for salt tolerance in Atriplex halimus L. Plant Physiol., 45: 62-5.

Munns, R., 2002. Comparative physiology of salt and water stress. Plant, Cell and Environ., 25: 239250.

Munns, R., 2005. Genes and salt tolerance: bringing them together. New Phytol., 167: 645 - 663.

Munns, R. and M. Tester, 2008. Mechanisms of salinity tolerance. Annual Review of Plant Biology, 59: 651-681.

Nakamura, Y., K. Tanaka, E. Ohta, and M. Sakata, 1990. Protective effect of external $\mathrm{Ca}^{2+}$ on elongation and the intracellular concentration of $\mathrm{K}^{+}$in intact mug bean roots under high $\mathrm{NaCl}$ stress. Plant and Cell Physiol., 31: 815 - 821.

Negrão, S., S.M. Schmöckel and M. Tester, 2017. Evaluating physiological responses of plants to salinity stress. Annals of Botany, 119: 1-11.

Nemat Alla, M.M., A.H.A. Khedr, M.M. Serag, A.Z. Abu-Alnaga, and R.M. Nada, 2012. Regulation of metabolomics in Atriplex halimus growth under salt and drought stress. Plant Growth Regul., 67: 281-304.

Nerd, A. and D. Pasternak, 1992. Growth, ion accumulation, and nitrogen fractioning in Atriplex barlayana grown at various salinities. J. Range Manage., 45:164 - 166.

Niinemets, Ü. and K. Kull, 1994. Leaf weight per area and leaf size of 85 Estonian woody species in relation to shade tolerance and light availability. For. Ecol. Manage., 70: 1-10. doi: 10.1016/03781127(94)90070-1

Niinemets, Ü., A. Portsmuth, and M. Tobias, 2006. Leaf size modifies support biomass distribution among stems, petioles and mid-ribs in temperate plants. New Phytol., 171: 91-104. doi: 10.1111/j.1469-8137.2006. 01741.x

Niinemets, Ü., A. Portsmuth, D. Tena, M. Tobias, S. Matesanz, and F. Valladares, 2007. Do we underestimate the importance of leaf size in plant economics? Disproportional scaling of support costs within the spectrum of leaf physiognomy. Ann. Bot., 100: 283-303. doi: 10.1093/aob/mcm107

Osborne, C.P., P.L. Mitchell, J.E. Sheehy, and F.I. Woodward, 2000. Modelling the recent historical impacts of atmospheric $\mathrm{CO} 2$ and climate change on Mediterranean vegetation, Global Change Biology, 6: 445-458.

Osmond, C.B., 1970. C4 photosynthesis in the Chenopodiaceae. z. Pflanzenphysiol., 62: 129-132.

Osmond, C.B., O. Björkman, and D.J. Anderson, 1980. Physiological Processes in Plant Ecology. Towards a Synthesis with Atriplex. Springer-Verlag, Berlin.

Poorter, H., and J.R. Evans, 1998. Photosynthetic nitrogen-use efficiency of species that differ inherently in specific leaf area. Oecologia, 116: 26-37. doi: 10.1007/s004420050560

Ramos, J., M.J. Lopez, and M. Benlloch, 2004. Effect of $\mathrm{NaCl}$ and $\mathrm{KCl}$ salts on the growth and solute accumulation of the halophyte Atriplex nummularia. Plant Soil, 259: 163-168

Rogers, M.E., A.D. Craig, R.E. Munns, T.D. Colmer, P.G.H. Nichols, C.V.Malcolm, et al., 2005. The potential for developing fodder plants for the salt- affected areas of southern and eastern Australia: an overview. Australian Journal of Experimental Agriculture 45: 301-329.

Rowell, D.L., 1994. Soil Science: methods and application. Longman Publishers, Singapore 350.

Rudolph, A.S., J.H. Crowe, and L.M. Crowe, 1986. Effect of three stabilizing agents-proline, betaine and trehalose, on membrane phospholipids. Arch. Biochem. Biophys., 245: $134-143$

Sairam, R.K., P.S. Deshmukh, and D.S. Shukla, 1997. Tolerance of Drought and Temperature Stress in Relation to Increased Antioxidant Enzyme Activity in Wheat, J. Agron. Crop Sci., 178: 171-178.

Smaoui, A., Z. Barhoumi, M. Rabhi, and C. Abdelly, 2011. Localization of potential ion transport pathways in vesicular trichome cells of Atriplex halimus L. Protoplasma, 248: 363- 372.

Sokół-Łętowska, A., 1997. Próby opracowania i zastosowania preparatów związków fenolowych wybranych surowców roślinnych jako przeciwutleniaczy. Zeszyty Naukowe Akademii Rolniczej we Wrocławiu. Technologia Żywności XI, 319: 99-115. 
Steel R.G.D., J.H. Torrie, and D.A. Dickie, 1980. Principles and Procedures of Statistics, $2^{\text {nd }}$ ed. Toronto: McGraw-Hill Publishing Company.

Sumanta, N., C.I. Haque, J. Nishika, and R. Suprakash, 2014. Spectrophotometric analysis of chlorophylls and carotenoids from commonly grown fern species by using various extracting solvents. Research Journal of Chemical Sciences, 4(9): 63-69.

Täckholm, V., 1974. Students' Flora of Egypt. $2^{\text {nd }}$ ed. (Beirut: Cairo University Press) 562 pp.

Tester, M. and R. Davenport, 2003. $\mathrm{Na}^{+}$tolerance and $\mathrm{Na}^{+}$transport in higher plants. Ann. Bot., 91: 503 $-527$.

Troughton, J.H. and K. Card, 1974. Leaf anatomy of Atriplex buchananii. New Zealand journal of botany, 12(2): 167-177.

Tozer, W.C., B. Rice, and M. Westoby, 2015. Evolutionary divergence of leaf width and its correlates. Am. J. Bot., 102: 367-378. doi: 10.3732/ajb.1400379

Uchiyama, Y., 1987. Salt tolerance of Atriplex nummularia. Technical Bulletin Tropical Agricultural Research Center Japan, 22: 1 - 69.

UNESCO, 1977. Map of the World Distribution of Arid Regions, MAB, Paris.

Viliers, A.J., I. Teichman, M.W. Rooyen, and J.K. Theron, 1996. Salinity induced changes on anatomy, stomatal counts and photosynthetic rate of Atriplex semibaccata. South Africa J. Bot., 62: $270-$ 276.

Vinocur, B. and A. Altman, 2005. Recent advances in engineering plant tolerance to abiotic stress: achievements and limitations. Curr. Opin. Biotechnol., 16:1- 10.

Walker, D.J., S. Lutts, M. Sanchez-Garcia, and E. Correal, 2014. Atriplex halimus L.: its biology and uses. J. Arid Environ., 100: 111-121.

Walsh, G.E., 1990. Anatomy of the seed and seedling of Spartina alterniflora Lois. (Poaceae). Aquatic Botany, 38: 177-193.

Wilson, C., S.M. Lesch, and C.M. Grieve, 2000. Growth stage modulates salinity tolerance of New Zealand Spinach (Tetragonia tetragonioides. Pall) and Red Orach (Atriplex hortensis L.). Ann. Bot., 85: $501-509$.

Wyn Jones, R.G., 1981. Salt tolerance. In: Johnson, C. B. (Ed.), Physiolgical processes limiting plant productivity, Butterworths, London, $271-292$.

Yentür, S., 2003. Bitki Anatomisi. İstanbul Üniversitesi, Fen Fakültesi, Biyoloji Bölümü, No: 227, İstanbul (in Turkish).

Zarrinkamar F., 2001. Foliar anatomy of the Caryophyllaceae family in Arasbaran, NW. Iran, Iran. Journ. Bot., 9 (I): 93-102.

Zielinski, A.A., C.M. Braga, I.M. Demiate, F.L. Beltrame, A. Nogueira, and G. Wosiacki, 2014. Development and optimization of a HPLC-RI method for the determination of major sugars in apple juice and evaluation of the effect of the ripening stage. Food Sci. Technol, Campinas, 34(1): 38-43. 